\title{
37. CHARACTERISTICS OF SEDIMENTS FROM FENI AND GARDAR DRIFTS, SITES 610 AND 611, DEEP SEA DRILLING PROJECT LEG 941
}

\author{
Philip R. Hill, Geological Survey of Canada, Bedford Institute of Oceanography, \\ Dartmouth, Nova Scotia, Canada ${ }^{2}$
}

\begin{abstract}
Sedimentary structures and grain-size spectra of drift sediments from Deep Sea Drilling Project Sites 610 and 611 are described. On the basis of structures, three facies are identified independent of lithology: homogeneous to burrowmottled sediment, partly bioturbated thin-bedded sediment, and laminated sediment. The homogeneous and bioturbated sediment facies predominate. Size spectra are controlled principally by the foraminifer and nannofossil contents of the samples. There is little evidence of current control of deposition, but more detailed analysis of vertical or lateral changes in size or compositional parameters might provide better direct evidence of current activity.
\end{abstract}

\section{INTRODUCTION}

During the course of DSDP Leg 94, two major oceanic sediment drifts with sediment-wave ornamentation were drilled: Feni Drift, Site 610, and Gardar Drift, Site 611 (Fig. 1). The main lithologic and stratigraphic results from these sites are described in the site reports and Kidd and Hill (this volume). Shipboard analysis of the cores from Sites 610 and 611 showed that the Pliocene to Quaternary sequences appeared to be predominantly pelagic or hemipelagic ooze and calcareous mud. There appeared to be very little evidence of current control of deposition despite the fact that large-scale sediment waves were drilled at both sites. This chapter provides some details of the sedimentological study carried out to establish whether there is any evidence of current activity from analysis of sedimentary structures, grain size, and coarse fraction composition. Cores recovered at both sites were sampled to describe the basic sediment characteristics, to compare sediment-wave trough and crest sequences over correlatable intervals (at paleomagnetic boundaries), and also to define sequential changes in grain size and composition through a glacial-interglacial cycle.

\section{METHODS}

The archive core halves were returned to the DSDP East Coast core repository at Lamont-Doherty Geological Observatory. Half-cores of sections that had been sampled for grain-size analysis on board ship were $x$-rayed. Samples from the Quaternary sequence (Zone NN19) at Site 610 were selected from approximately the same stratigraphic levels in crest and trough holes using detailed visual correlation of the ooze and calcareous mud beds (Ruddiman et al., this volume). Three Pliocene intervals from crest and trough holes were sampled at Site 611: (1) an interval at the Matuyama/Gauss boundary (2.47 Ma); (2) an interval at the Gauss/Gilbert boundary (3.40 Ma); and (3) an interval at approximately $3.75 \mathrm{Ma}$, estimated from visual correlation and the shipboard accumulation-rate curve. Grain-size analyses were carried

\footnotetext{
${ }^{1}$ Ruddiman, W. F., Kidd, R. B., Thomas, E., et al., Init. Repts, DSDP, 94: Washington (U.S. Govt. Printing Office).

2 Address: Geological Survey of Canada, Atlantic Geoscience Centre, Bedford Institute of Oceanography, P.O. Box 1006, Dartmouth, Nova Scotia, B2Y 4A2, Canada
}

out at the Atlantic Geoscience Centre of the Geological Survey of Canada. Because of the high biogenic content of all the samples, they were initially processed for size analysis with a minimal amount of destructive treatment. The samples were soaked in water overnight, then washed gently through a $53-\mu \mathrm{m}$ sieve. Hydrogen peroxide and ultrasonic treatment, which might have led to the destruction of foraminifer tests, were deliberately not used at this stage of the processing. Size analysis of subsamples of the coarse $(>53-\mu \mathrm{m})$ and fine $(0.5--53-\mu \mathrm{m})$ fractions were performed using a settling tube and sedigraph, respectively. These methods were used because the resulting data are in the form of "equivalent settling diameters," which can be interpreted in terms of current velocities. A small quantity of Calgon was used in the sedigraph to disperse the fine fraction in each sample.

Most of the ooze samples were successfully treated in this way. However, most of the calcareous mud samples were not completely disaggregated, and large pellets of mud remained in the coarse fraction. Where a sufficient quantity of the sample was left over, the coarse fractions were reprocessed using a small quantity of hydrogen peroxide and a few seconds exposure to ultrasound. These samples were reweighed and a corrected value obtained for the sand-fraction percent. It was not possible to carry out settling-tube analyses on these reprocessed samples. The fine fractions were examined selectively by placing a drop of the dispersed sample on a microscope slide and viewing at high magnification $(500 \times)$. No pellets were observed in the suspension and the fine particles exhibited Brownian motion, suggesting that the samples were adequately dispersed.

\section{STRATIGRAPHY}

At Site 610, drilling penetrated to lower Miocene sediments at $720 \mathrm{~m}$ sub-bottom (Fig. 2). The sequence consists of Miocene nannofossil chalk overlain by lower Pliocene ooze and upper Pliocene siliceous nannofossil ooze. Overlying this thick ooze-chalk unit is a sequence of interbedded calcareous mud and nannofossil ooze of late Pliocene and Quaternary age, which represent glacialinterglacial climatic fluctuations. Site 611 shows a similar stratigraphy (Fig. 2), although marly ooze was deposited as early as the early Pliocene. Samples were taken from the Quaternary sequence at Site 610 and from both Quaternary and Pliocene sections at Site 611.

\section{SEDIMENTARY STRUCTURES}

Fourteen core sections from the two sites were $\mathrm{x}$-rayed (Table 1) to examine sedimentary structures. Three facies can be distinguished in the cores. 


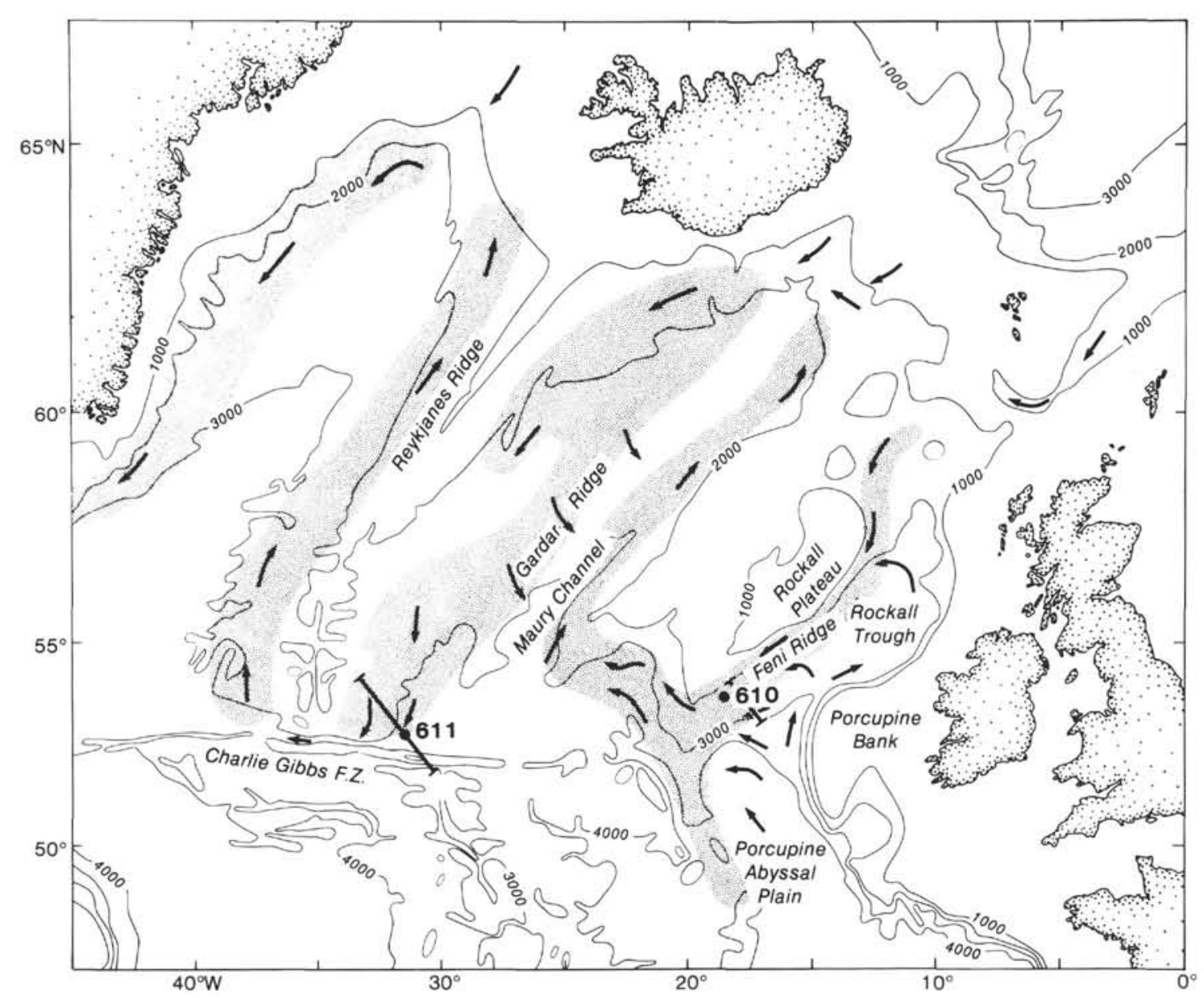

Figure 1. Location map of the North Atlantic showing major sediment drifts (shaded areas) and the location of Leg 94 Sites 610 and 611 . Bathymetric contours in meters.

Homogeneous to burrow-mottled sediment makes up the largest proportion of the $\mathrm{x}$-rayed cores. The common characteristic of this facies is the absence of primary sedimentary structures (Fig. 3 ). The ooze beds are most commonly homogeneous, whereas the calcareous muds generally show a greater diversity of bioturbation structures including Zoophycos. The best visible burrow structures, however, are preserved at boundaries between calcareous mud and ooze or between subunits of calcareous mud beds (Fig. 3C). Gravel-sized clasts or dropstones are common in the calcareous mud beds.

Partly bioturbated thin-bedded sediment is recognized where subtle lithological differences can be seen in X-radiographs (Fig. 4). The beds are generally on the order of a centimeter or two thick, and bed boundaries are poorly defined as a result of bioturbation. This type of bedding is seen in both calcareous mud and ooze lithologies, but early diagenetic changes in the ooze beds may provide the density contrast observed in X rays. These structures may not always represent primary bedding.

Laminated sediments are occasionally present, but are restricted to ooze units (Fig. 5). The laminae are on the order of $1 \mathrm{~mm}$ thick and are found in sequences several centimeters thick (Fig. 5A) or in isolation (Fig. 5B). In many cases, laminated sections in $\mathrm{X}$ ray correspond to gray green, relatively indurated laminae observed in the initial core descriptions, particularly in the deeper, chalkier sections of the holes. The induration is clearly an early diagenetic effect, but the laminae may reflect initial size or composition differences and thus be primary sedimentary structures.

\section{GRAIN SIZE}

Size analyses were conducted on calcareous mud and ooze beds from both sites. Significantly different size spectra related to lithology and site were observed (Fig. 6). Ooze from Site 610 shows three modes, one in the sand fraction ( $>64 \mu \mathrm{m}$ ), one at 6.0 to $6.5 \phi(10-15 \mu \mathrm{m})$ and one at 8.0 to $8.5 \phi(3-4 \mu \mathrm{m})$ (Fig. 6). Most samples also showed a minimum at $5.0 \phi(30 \mu \mathrm{m})$, which may in part be related to the merge-program used when combining settling-tube and sedigraph data. Calcareous mud from the same site contains a similar sand-fraction mode but shows a broad distribution over the silt and clay range with no distinct modes (Fig. 6). The 6.5- and 8.5- $\phi$ modes can be distinguished in samples taken near boundaries with the ooze, indicating a mixed size distribution.

Ooze from Site 611 contains only two modes, in the sand fraction and at 7.5 to $8.5 \phi(3-5 \mu \mathrm{m})$. There is no mode at $6.5 \phi$ in all the samples examined from this site. Consequently, there is a very marked minimum in the spectra at $5.0 \phi(30 \mu \mathrm{m})$. Calcareous mud from Site 611 


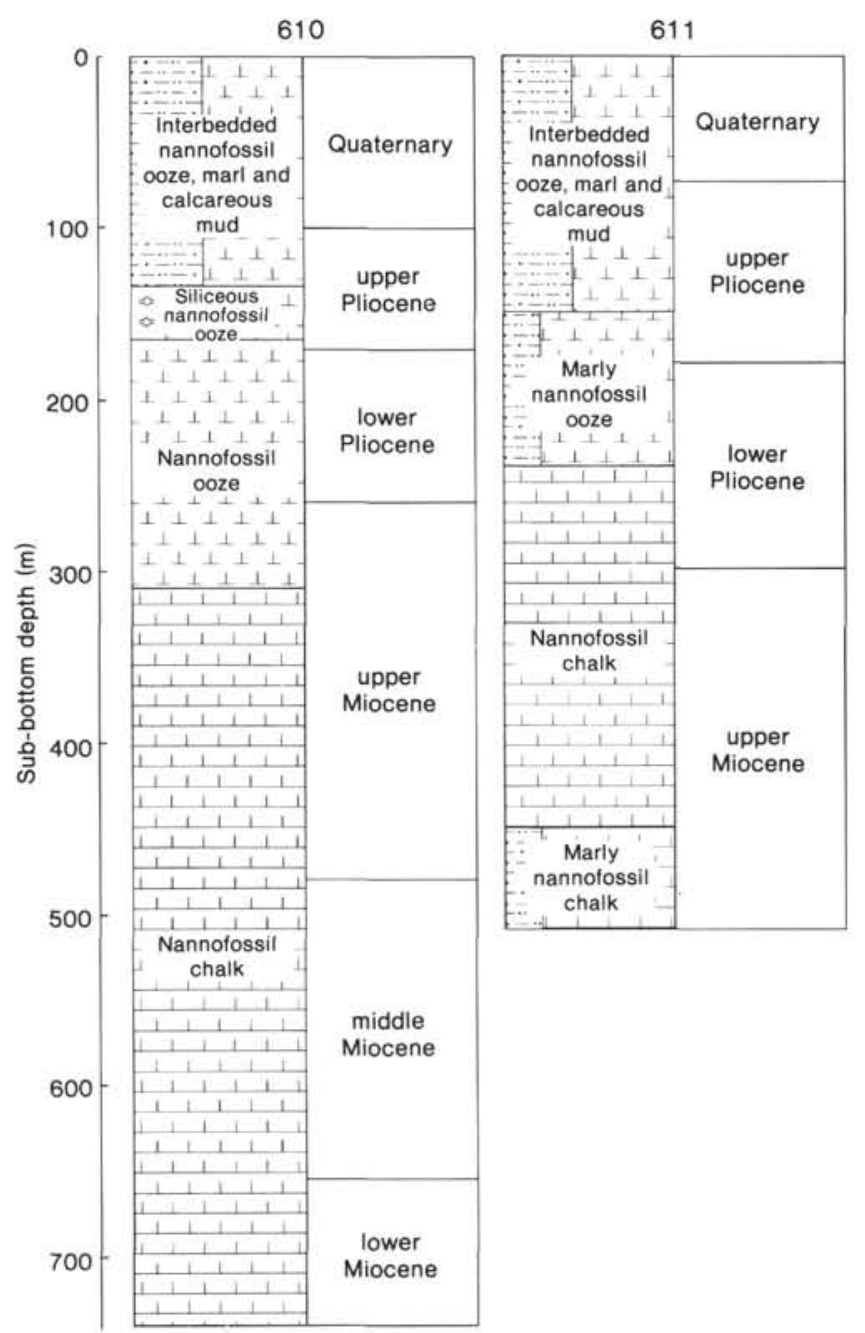

Figure 2. Stratigraphic summary of Sites 610 and 611.

Table 1. Sections $\mathrm{x}$-rayed in this study.

\begin{tabular}{l} 
Hole-core-section \\
\hline $610-4-6$ \\
$610 \mathrm{~A}-6-5$ \\
$610 \mathrm{~B}-7-3$ \\
$610 \mathrm{D}-4-5$ \\
$610 \mathrm{D}-3-3$ \\
$611-13-3$ \\
$611-13-4$ \\
$611 \mathrm{~A}-3-3$ \\
$611 \mathrm{~A}-3-4$ \\
$611 \mathrm{C}-15-2$ \\
$611 \mathrm{C}-15-3$ \\
$611 \mathrm{C}-20-2$ \\
$611 \mathrm{C}-22-6$ \\
$611 \mathrm{D}-10-3$ \\
$611 \mathrm{D}-13-6$ \\
\hline
\end{tabular}

shows a broad amodal distribution in the silt and clay range similar to the muds at Site 610 .

The various modes can be explained by the biogenic composition of the samples. The irregular mode in the sand fraction consists primarily of planktonic foraminifers, with minor quartz and volcanic ash. Rarely, quartz and ash predominate, possibly as a result of foraminifer dissolution. The 7.5- to 8.5- $\phi$ mode in samples from both sites are formed by the dominant nannofossil types such as Pseudoemiliania lacunosa (Pleistocene) and Reticulofenestra pseudoumbilica (Pliocene). The 6.5- $\phi$ mode in the Site 610 samples probably corresponds to the presence of large numbers of reworked Cretaceous nannofossils (see Site 610 report), which are generally much larger than the Neogene specimens (Haq, 1978).

\section{Vertical Variations}

Apart from the mixing effect at calcareous mud-ooze bed boundaries, significant changes in grain size with depth can only be detected in the coarse fraction ( $>64$ $\mu \mathrm{m})$. A vertical profile through Section 611A-3-4 is shown in Figure 7 and demonstrates that there are fluctuations in size both between mud and ooze beds and within mud intervals. Comparing the size fluctuations with composition (Fig. 7), at least two factors appear to control the fluctuations: (1) the absence of foraminifers near the top of the calcareous mud interval, and (2) the increase in the coarse terrigenous fractions (quartz, volcanic glass, and minor minerals) in the same interval.

The sudden disappearance of foraminifers from the coarse fraction is most probably related to dissolution at the end of glacial intervals (Ruddiman et al., 1980). Changes in terrigenous composition are directly related to the supply of ice-rafted glacial sediment.

\section{Trough-to-Crest Variations}

Samples were taken at both sites from intervals that could be correlated between sediment wave crest and trough to within a centimeter of two (see frontispiece, this volume). At Site 610 the sampling was based on lithological correlations (Ruddiman et al., this volume), and at Site 611, the samples were taken around paleomagnetic boundaries. Comparison of the size distributions (Fig. 8) show that the variations from crest to trough are no greater than the vertical variations noted in the previous section. Even in the examples shown, there is no consistent coarsening or fining from crest to trough. No other differences in lithology or sedimentary structures were observed.

\section{DISCUSSION}

Current meter data from the Feni Drift area (Dickson and Kidd, this volume) indicates that currents with a speed of up to $39 \mathrm{~cm} / \mathrm{s}$ may be present near the seabed. The number of samples analyzed in this study was small, but no clear evidence for current control of sedimentation was observed on either the Feni or Gardar drifts. There are very few well-preserved primary sedimentary structures, and the small variation in grain size can be explained by glacial to interglacial changes in sediment supply and possibly dissolution. The few, poorly preserved examples of primary structures, however, could result from rapid deposition influenced by current sorting. Overall rates of accumulation have been only slightly greater than average pelagic accumulation rates in the Atlantic (Davies et al., 1977; Baldauf et al., this volume), so that bioturbation would have removed most 

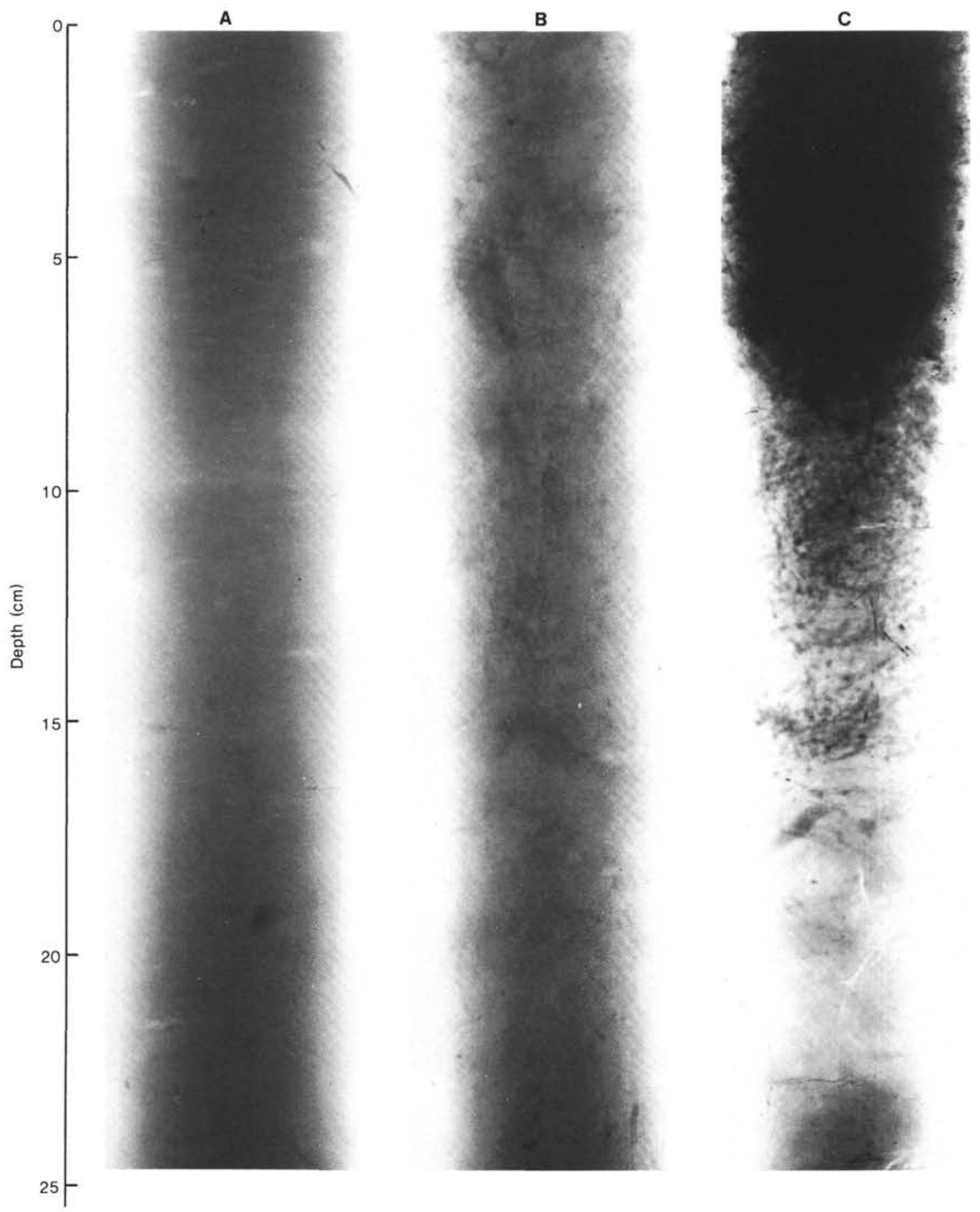

Figure 3. $\mathrm{X}$ rays of the homogeneous to burrow-mottled facies. A. Ooze, Section 610-4-6. B. Calcareous mud, Section 611A-3-3. C. Bioturbated boundary within calcareous mud bed, Section 611-13-4.

evidence of current activity. The lack of primary sedimentary structures has been noted in other areas of low net accumulation rates where high current velocities are presently observed, and where rapid erosion and deposition take place (Hollister and McCave, 1984). Thus although very little positive evidence is present to indicate strong current control at the drift sites, it is quite possible that such currents did exist.

The characteristics described in this chapter are similar to those described for "muddy contourites" by Stow
(1982), although the composition of the Feni and Gardar sediment is primarily pelagic. Stow and Holbrook (1984) have interpreted similar pelagic sediments on the Hatton Drift as contourites on the basis of the drift morphology, differential rates of sediment accumulation, and the known present-day hydrographic regime. However, these characteristics and the standard sequence for muddy contourites described by Stow (1982) do not distinguish the sediments from "pelagites" (Stow and Piper, 1984), which show differential accumulation rates and 

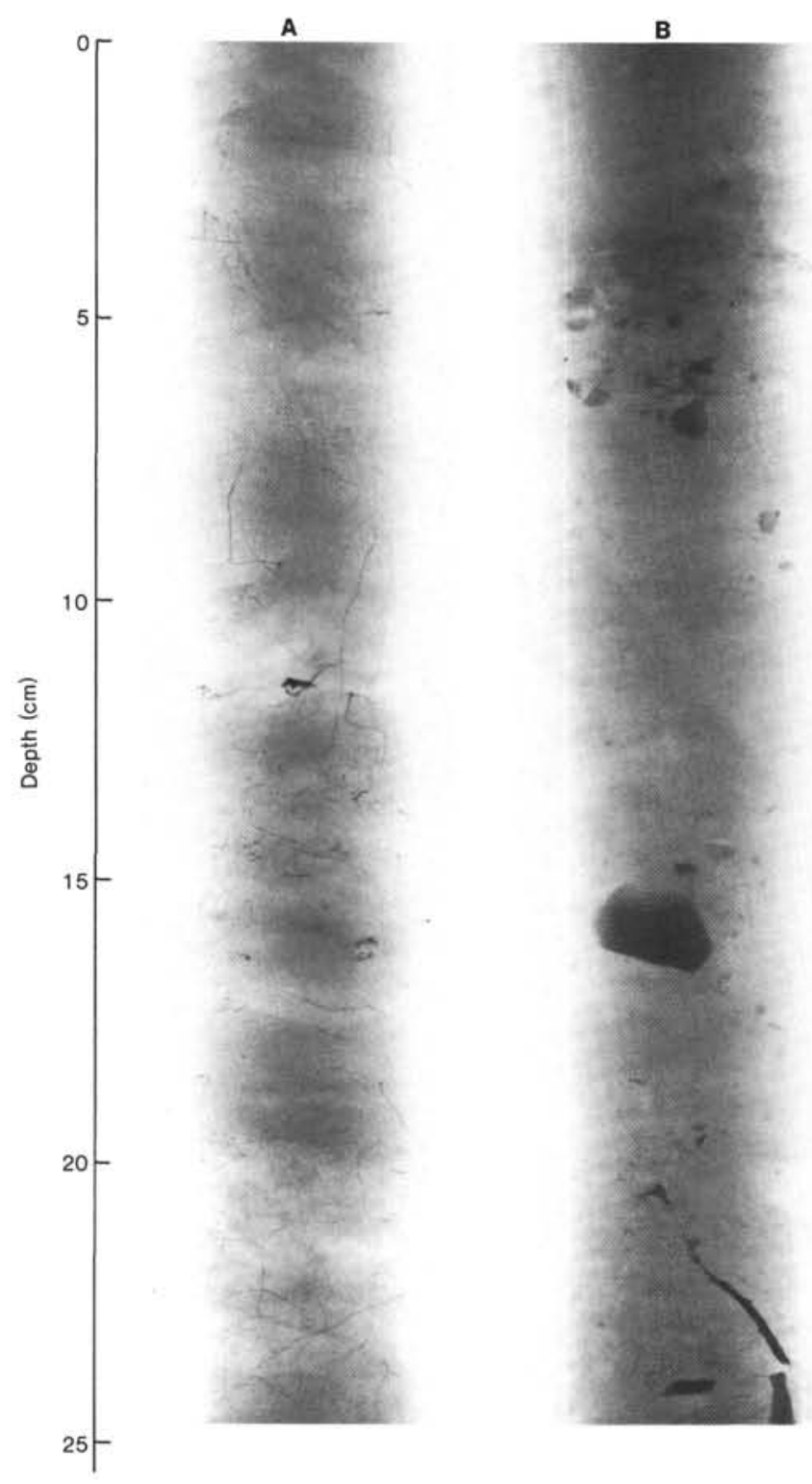

Figure 4. X rays of partly bioturbated, thin-bedded facies. A. Ooze, Section 611C-15-2. B. Calcareous mud, Section 610D-3-3.

grain-size changes as a result of climatic fluctuations or dissolution cycles. More detailed analysis of (1) the areal distribution of grain size and composition across the sediment drift (Faugeres et al., in press) and (2) vertical sequences (Gonthier et al., 1984) provide more positive methods of identifying current control of sedimentation. The small sequence analysis carried out in the present study was not adequate to resolve the effects of current control from those caused by Pleistocene climatic variations of sediment supply or dissolution. Grain-size analysis of samples from the laminated sequences should be carried out. It may be possible to resolve current effects in a more detailed study over a longer sequence, perhaps by employing spectral analysis to distinguish cycles of current-controlled grain-size fluctuations from supply or dissolution controls. Alternatively, a study of the Pliocene sequence deposited before the initiation of Northern, Hemisphere glaciations, but under the influence of Antarctic glaciations (and hence possible bottom-water fluctuations), may be more productive.

\section{ACKNOWLEDGMENTS}

Part of this work was carried out at the Grant Institute of Geology while I was a visiting scientist. I would like to thank the Nuffield Foundation for support, Professor G. Y. Craig and Dorrik Stow for their hospitality, and Dorrik for discussions on contourites. Thanks also to Donald Clattenburg of the Sedimentology Lab of Atlantic Geoscience Centre for his patience concerning the grain-size samples that would not disaggregate. D. S. Gorsline, D. J. W. Piper, D. A. V. Stow, and J. P. M. Syvitski reviewed the manuscript.

\section{REFERENCES}

Davies, T. A., Hay, W. W., Southam, J. R., and Worsley, T. R., 1977. Estimates of Cenozoic oceanic sedimentation rates. Science, 197: 53-55.

Faugeres, J.-C., Gonthier, E., and Stow, D. A. V., in press. Interpretation of lithological and textural variation in contourite sediments, with an example from the Gulf of Cadiz. Mar. Geol.

Gonthier, E. G., Faugeres, J.-C., and Stow, D. A. V., 1984, Contourite facies of the Faro Drift, Gulf of Cadiz. In Stow, D. A. V., and Piper, D. J. W. (Eds.), Fine-Grained Sediments: Deep Water Processes and Facies. Geol. Soc. London Spec. Publ., 15:275-292.

Haq, B. U., 1978. Calcareous nannoplankton. In Haq. B. U., and Boersma, A. (Eds.), Introduction to Marine Micropaleontology: New York (Elsevier), pp. 79-107.

Hollister, C. D., and McCave, I. N., 1984. Sedimentation under deepsea storms. Nature, 309:220-225.

Ruddiman, W. F., Molfino, B., Esmay, A., and Pokras, E., 1980. Evidence bearing on the mechanism of rapid deglaciation. Climatic Change, 3:65-87.

Stow, D. A. V., 1982. Bottom currents and contourites in the North Atlantic. Bull. Inst. Geol. Bassin d'Aquitaine, Bordeaux, 31:151166.

Stow, D. A. V., and Holbrook, J. A., 1984. Hatton Drift contourities, Northeast Atlantic, Deep Sea Drilling Project Leg 81. In Roberts, D. G., Schnitker, D., et al., Init. Repts. DSDP, 81: Washington (U.S. Govt. Printing Office), 695-700.

Stow, D. A. V., and Piper, D. J. W., 1984. Deep-water fine-grained sediments: facies models. In Stow, D. A. V., and Piper, D. J. W. (Eds.), Fine-Grained Sediments: Deep-Water Processes and Facies. Geol. Soc. London Spec. Publ., 15:611-646.

Date of Initial Receipt: 15 April 1985

Date of Acceptance: 25 October 1985 


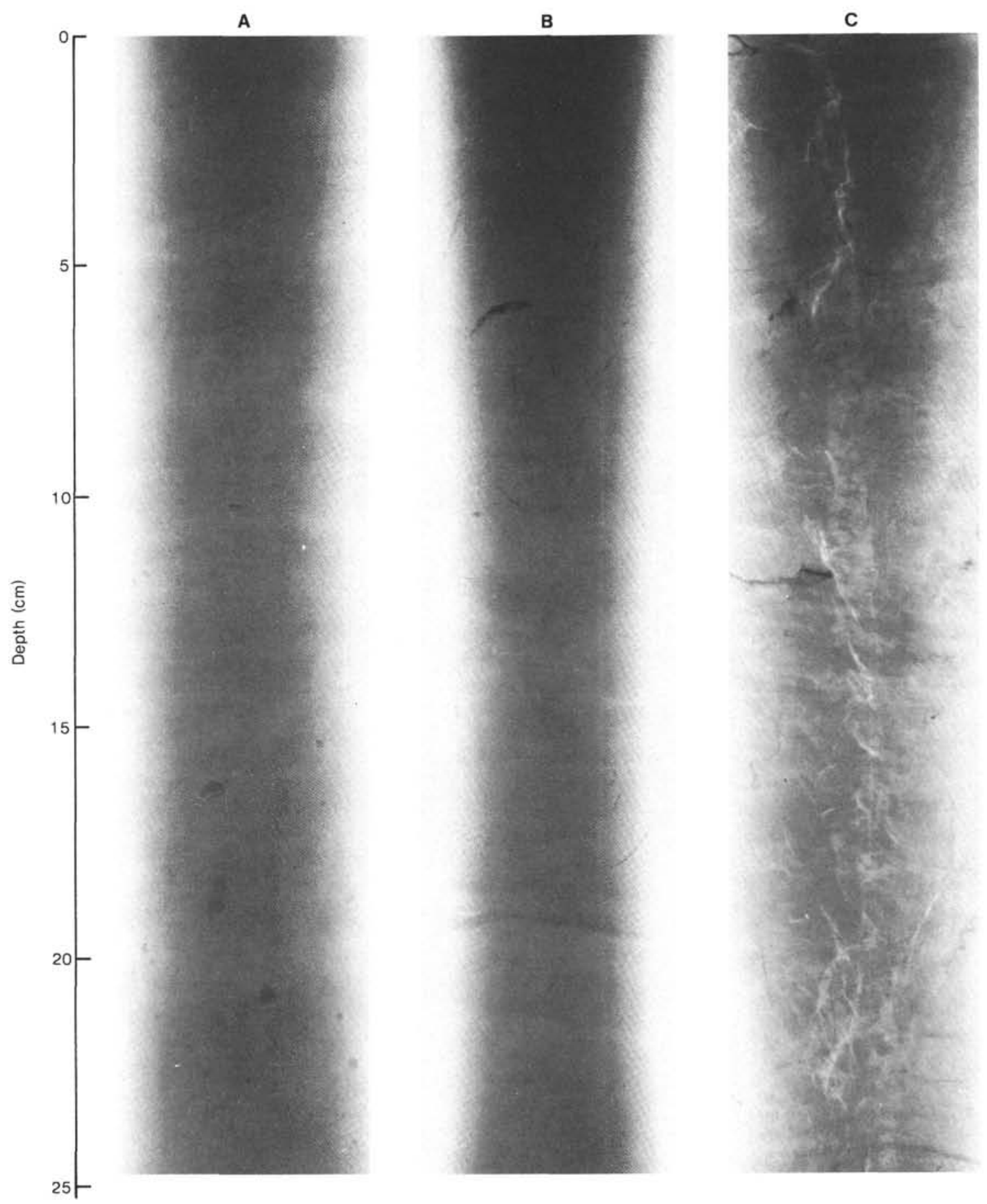

Figure 5. X rays of the laminated facies. A. Ooze, Section 610A-6-5. B. Isolated laminae, Section 610B-7-3. C. Chalky section, Section 611C-22-6. 


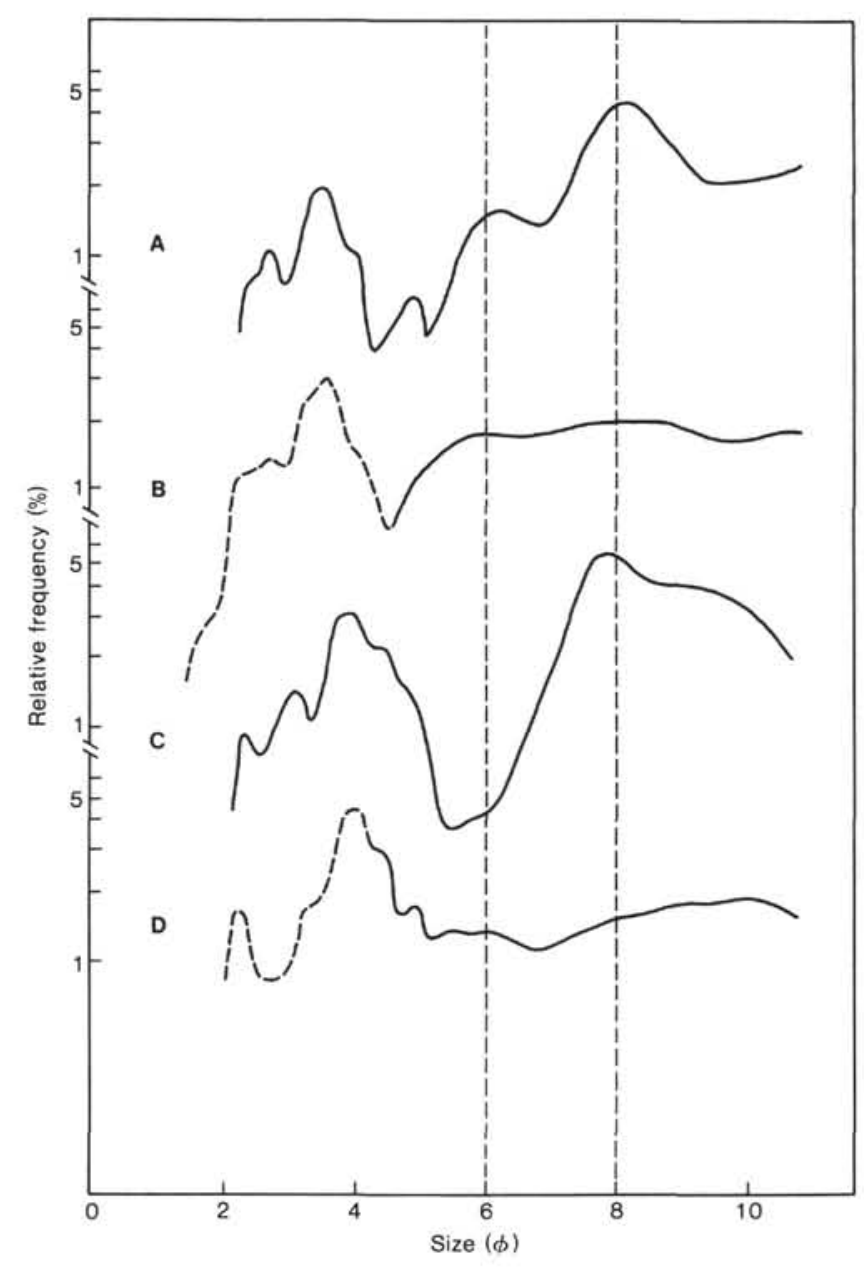

Figure 6. Grain-size spectra illustrating the dominant modes in the sand fraction and at $6.5 \phi$ and $8.0 \phi$. A. Ooze, Sample 610B-7-3, $137-138 \mathrm{~cm}$. B. Calcareous mud, Sample 610D-4-5, 63-64 cm. C. Ooze, Sample 611C-20-2, 82-83 cm. D. Calcareous mud, Sample $611 \mathrm{~A}-3-4,56-57 \mathrm{~cm}$. Note that the coarse fraction spectra in calcareous mud samples (dashed segments) are not true spectra due to disaggregation problems.

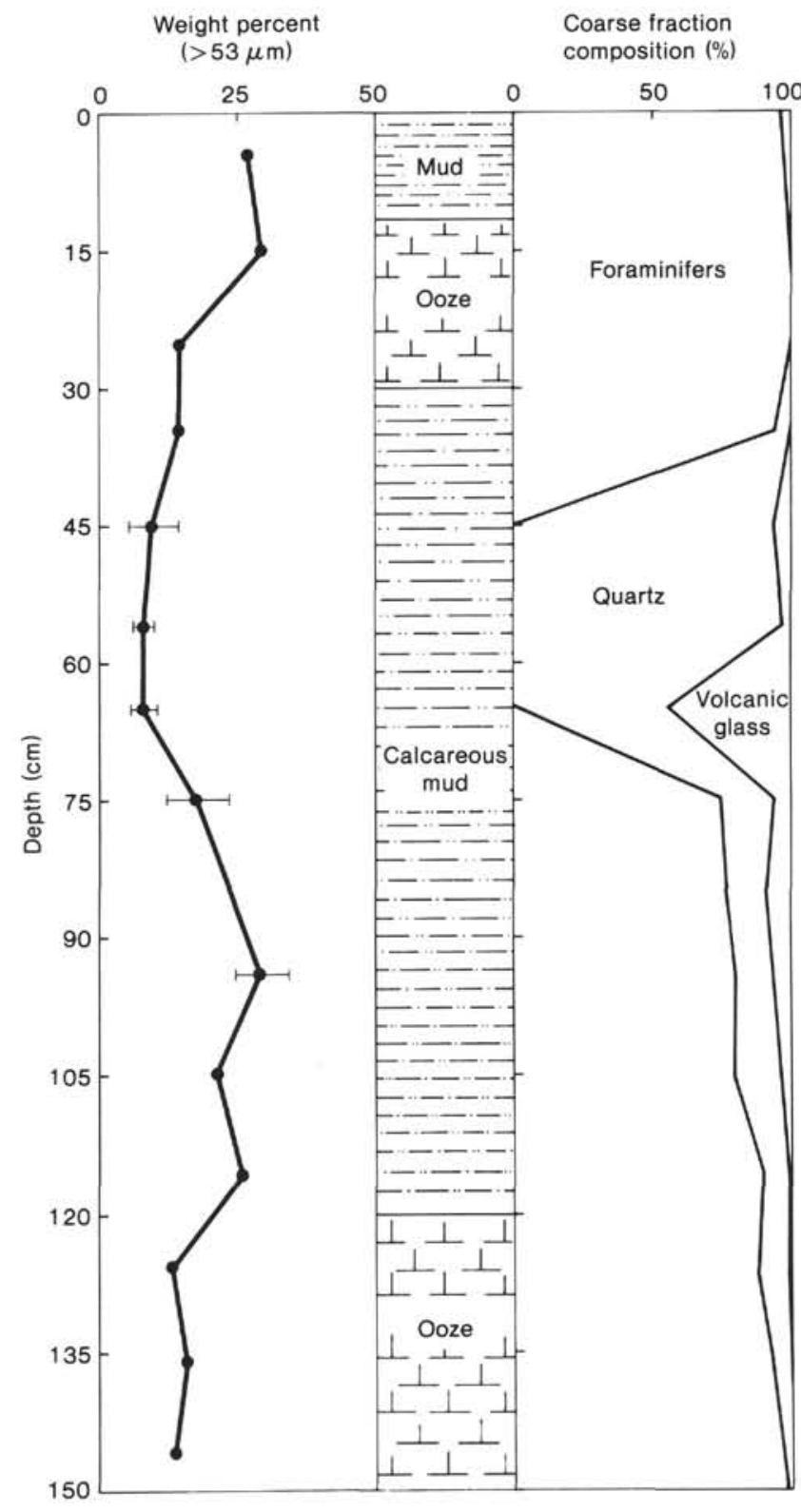

Figure 7. Vertical sequence of grain size and composition through Section 611A-3-4. 
P. R. HILL

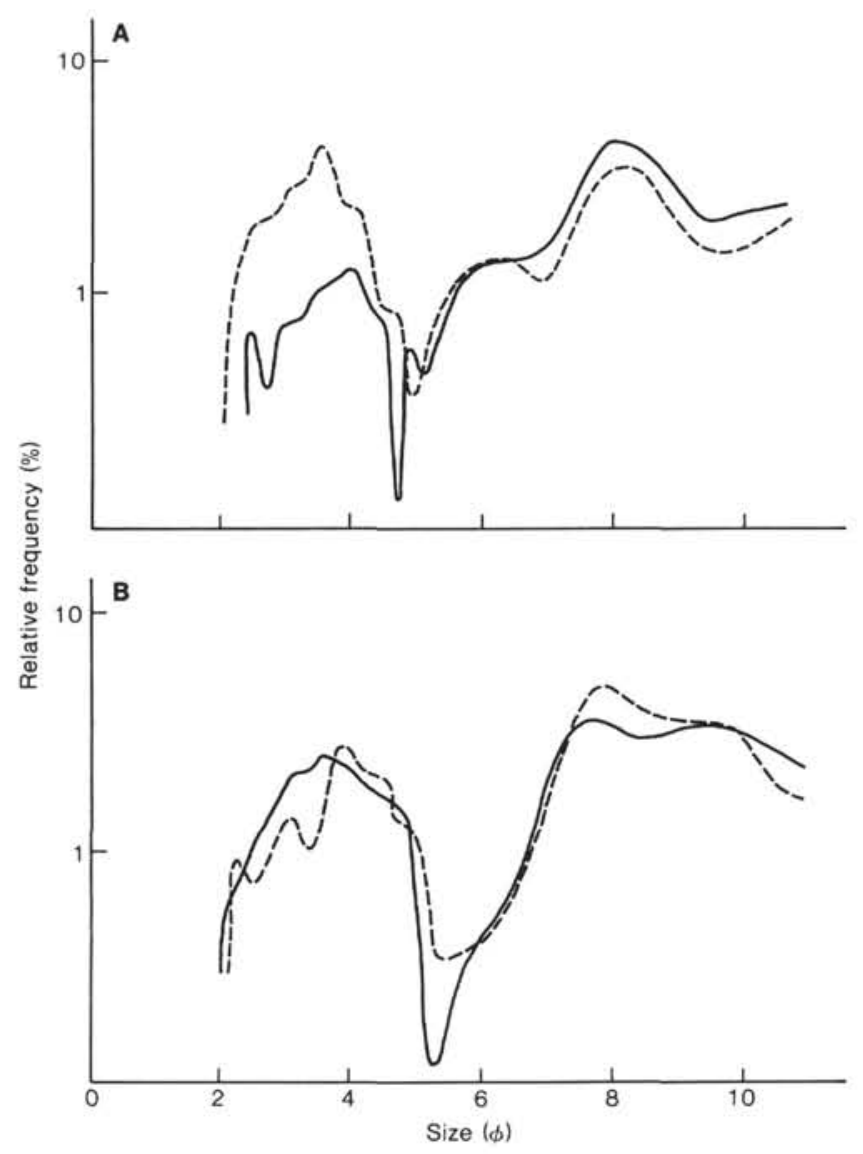

Figure 8. Comparison of sediment wave crest (solid) and trough (dashed) grain-size spectra for A. Site 610 (Sample 610B-7-3, 137$138 \mathrm{~cm}$; Sample 610D-4-5, 63-64 cm) and B. (Sample 611C-20-2, 82-83 cm; Sample 611D-10-3, 50-51 cm). 